\title{
Cosmetic Activities of Nyasol from the Rhizomes of Anemarrhena asphodeloide
}

\author{
Yhun Jung Park $\cdot$ Chang-Sub Ku $\cdot$ Min-Jin Kim $\cdot$ Mi Kyeong Lee $\cdot$ Ki Ohk \\ Kim · Hyung Won Ryu · Hyuk-Hwan Song • Doo Young Kim - Sei-Ryang Oh*
}

\section{지모의 뿌리줄기로부터 분리된 nyasol의 미용효과}

박윤정·구창섭 · 김민진 · 이미경 · 김기옥·류형원·송혁환·김두영 · 오세량*

Received: 11 August 2014 / Accepted: 2 October 2014 / Published Online: 31 March 2015

(C) The Korean Society for Applied Biological Chemistry 2015

\begin{abstract}
The rhizomes of Anemarrhena asphodeloide was extracted with $100 \%$ ethanol and concentrated subfractions were separated with medium pressure liquid chromatography-based activity profiling. One compound was isolated from the subfraction 10 through the repeated preparative high performance liquid chromatography (prep-HPLC). According to physico-chemical and spectroscopic data including NMR and MS, the chemical structures of the compound was determined as nyasol (1). Nyasol was exhibited potent inhibitory activity for $\mathrm{NO}\left(\mathrm{IC}_{50}: 12.5 \mu \mathrm{g} / \mathrm{mL}\right)$, tyrosinase $\left(\mathrm{IC}_{50}: 12.5 \mu \mathrm{g} / \mathrm{mL}\right)$, melanin contents $\left(\mathrm{IC}_{50}: 12.5 \mu \mathrm{g} / \mathrm{mL}\right)$, thymus and activation-regulated chemokine (TARC) production $\left(\mathrm{IC}_{50}: 6.25 \mu \mathrm{g} / \mathrm{mL}\right)$. As a result, nyasol has an excellent inflammationdependent anti-whitening and TARC production activity. It could be used to a large range of functional cosmetics.
\end{abstract}

Y. J. Park · K. O. Kim · H. W. Ryu $\cdot$ H.-H. Song $\cdot$ D. Y. Kim · S.-.R Oh Natural Medicine Research Center, KRIBB, Cheongju 363-883, Republic of Korea

C.-S. Ku $\cdot$ M.-J. Kim

Organic and Natural Product Research Center, Cotde Inc., Jeju Technopark, 4-8 Ara-1 dong, Jeju-City, Republic of Korea

Y. J. Park $\cdot$ M. K. Lee

College of Pharmacy, Chungbuk National University, Cheongju 361-763, Republic of Korea

*Corresponding author (S.-.R Oh: seiryang@kribb.re.kr)

Y. J. Park and C.-S. Ku contributed equally.

This is an Open Access article distributed under the terms of the Creative Commons Attribution Non-Commercial License (http://creativecommons. org/licenses/by-nc/3.0/) which permits unrestricted non-commercial use, distribution, and reproduction in any medium, provided the original work is properly cited.
Keywords Anemarrhena asphodeloide $\cdot$ anti-atopy $\cdot$ antiwhitening $\cdot$ nitric oxide $\cdot$ nyasol

\section{서 론}

지모(Anemarrhena asphodeloide)는 백합과(Liliaceae)에 속하는 다년생 초본으로써 근경을 약재로 사용하며 한방에서는 해열, 당뇨, 소염, 진해, 거담 등의 목적으로 사용되고 있다. 보고된 약리학적 작용으로는 해열작용, 강심작용, 이뇨작용, 항균작용, 거담작용, 진정작용, 혈당강하작용, 항암작용이 있는 것으로 알 려져 있다(Kim 등, 1999; Son 등, 1999). 지모의 주요 성분으 로는 steroid saponin계열인 timosaponin A-I, A-III, B-II, anemarsaponin B, F-gitonin, smilageninoside, degalactotigonin 등(Kawasaki 등, 1963; Kawasaki와 Yamauchi, 1963; Niwa 등, 1988; Nahumo 등, 1991)과 xanthone 계열의 polyphenol 화합물들인 mangiferin, isomangiferin, neomangiferin 등이 보고 되어 있다(Morita 등, 1965; Sun 등, 1992). 특히 timosaponin A-III는 혈당강하작용과 항암 활성(Nakashima 등, 1993; Kimura 등 1996), anemarsaponin B는 in vitro에서 PAF-induced rabbit platelet aggregation을 억제하는 효과가 있다고 보고 되어있다 (Dong과 Han, 1991).

의학기술이 발전되고 현대 사회의 생활 수준이 향상됨에 따 라 평균 수명이 증가하는 고령화 사회로 접어들면서 다양한 질 병과 질환들에 대해 천연물 소재들을 활용한 연구가 증가하고 있다(Azuma 등, 1999; Park 등, 2003a; Cho, 2007). 천연물 성분들의 약리적 기능이 과학적으로 입증되고, 기능성 화장품의 수요 증가 및 시장 규모가 확대됨에 따라 천연 기능성 화장품 의 개발은 활발히 진행되어가고 있다(Cho, 2011; Cho 등, 2011). 
화장품의 기능성 연구는 주로 미백효과에 집중되어 있다. 피 부에 활성산소가 과량 존재하면 체내의 항산화 물질이 고갈되 면서 멜라닌 생성 반응이 증가되고 이는 각질형성세포를 활성 화하여 cytokine 분비를 촉진하게 되어 멜라닌 세포의 증식과 합성을 증가시켜 피부의 색소침착, 기미 형성이 증가된다 (Yamakoshi 등, 2003). 멜라닌 생성은 기저층에 존재하는 색소 세포(melanocyte) 내의 melanosome에 의해 생합성 된다. 멜라 닌의 주요 기작은 주요 효소인 tyrosine이 tyrosinase에 의해 산 화되어 dihydroxyphenyl-alanine (DOPA), DOPA quinone이 되 고 이것이 다시 5,6-dihydroxyindole, indole-5,6-quinone로 자동 산화되어 최종 반응으로 멜라닌 중합체를 형성하는 것으로 알 려져 있다. 따라서 피부 미백제의 개발에 있어서 tyrosinase활성 억제 실험은 유용한 평가법으로 인정되고 있다(Prota, 1980; Pavel과 Muskite, 1983; Hearing과 Jimenez, 1987; Ko, 2000).

최근 아토피 피부염 동물 모형에서 thymus and activationregulated chemokine (TARC)와 macrophage-derived chemokine (MDC)의 피부 발현이 증가되는 것으로 보고되어 있다 (Vestergaard 등, 2000). Chemokine은 다양한 종류의 백혈구의 이동과 활성화를 조절하는 cytokine으로 조직으로의 염증세포의 침윤을 조절한다(Yoshie 등, 2001). Th2 세포는 chemokine receptor-4 (CCR4)를 발현하며, $\mathrm{CCR} 4$ 는 $\mathrm{TARC}, \mathrm{MDC}$ 의 수용 체이며 Th2 세포의 migration을 선택적으로 조절한다(Rha, 2005).

본 연구에서는 지모 추출물에서 medium pressure liquid chromatography (MPLC)와 연계한 활성유도 분획법(bioactivityguided fractionation)을 이용하여 항염 효과를 가지는 물질이 있 음을 확인하였고 해당 활성 단일화합물을 분리하고 항염증, 피 부 미백, 항아토피 효과 등의 약리적 미용 활성을 탐색하여 천 연 기능성화장품 소재로서의 가능성을 검토하였다.

\section{재료 및 방법}

실험 재료. 본 실험에 사용한 지모(A. asphodeloide)의 뿌리줄 기는 2013년 제주도에서 구매한 것으로, (주) 콧데(http://www. cotde.co.kr/)에서 제공받아 사용하였다.

시약 및 기기. 실험에 사용한 세포주인 RAW264.7 cell, $\mathrm{B} 16 \mathrm{~F} 10$ cell, $\mathrm{HaCaT}$ cell은 한국 세포주 은행(Korean Cell Line Bank)으로부터 구입하였으며 세포배양을 위해 $1 \%$ antibiotic, $10 \%$ fetal bovine serum (FBS), phosphate buffered saline (PBS), Dulbecco's Modified Eagle's Medium (DMEM) 은 Gibco (USA)에서 구입하였다. 세포 독성과 활성 평가를 위 해 non-radioactive cytotoxicity assay kit (Promega, USA)를 사용하였고, Lipopolysaccharide (LPS), 3-(4,5-dimethylthiaxo-2yl)-2,5-diphenyl tetrazolium bromide (MTT), ascorbic acid, dimethyl sulfoxide (DMSO), L-3,4-dihydroxyphenylalanine (LDOPA), tyrosinase, arbutin, kojic acid, xanthine, xanthine oxidase는 Sigma-Aldrich (USA)에서 구입하여 사용하였다. TARC, MDC의 양은 human ELISA kit와 recombinant human $\mathrm{IFN}-\gamma, \mathrm{TNF}-\alpha$ (R\&D Systems, USA)를 사용하여 SpectraMax M5 (Molecular Devises, USA)로 측정하였다. MPLC Puriflash 450(Interchim, France)과 high performance liquid chromatography (HPLC)급 methanol (MeOH) 용매(Honeywell, USA)를 사용하여 활성물질을 분리하였고, 분리한 활성물질의 분석과 구
조분석은 Ultraperformance liquid chromatography-quadrupole time of flight-mass spectrometry (UPLC-QTOF-MS, Waters, USA), Bruker AM400 ( ${ }^{1} \mathrm{H}-\mathrm{NMR}$ at $400 \mathrm{MHz},{ }^{13} \mathrm{C}-\mathrm{NMR}$ at $100 \mathrm{MHz}$, Billerica, USA), acetonitrile (ACN) 용매(Honeywell, USA), methanol- $d_{4}$ (Cambridge Isotope Laboratories, USA)를 사용하였다.

지모 추출물 조제 및 활성물질 분리. 음건한 지모 뿌리줄기 $15 \mathrm{~g}$ 을 잘게 분쇄하여 $100 \%$ ethanol $(\mathrm{EtOH}, 1 \mathrm{~L} \times 3)$ 을 가하여 실온에서 24 시간 3 회 반복 추출한 후 여과하였다. 얻어진 여액 을 감압 농축하여 $\mathrm{EtOH}$ 추출물 $(6.8 \mathrm{~g}$, 추출 수율 $45.3 \%)$ 을 얻 었다. 얻은 추출물 $6.8 \mathrm{~g}$ 을 MPLC 기기에 $5 \times 25 \mathrm{~cm}$ 에 Zeoprep $\mathrm{C}_{18}, 45-60 \mathrm{~mm}$ 를 충진한 칼럼관과 $\mathrm{UV}$ 검출기 $(254,275 \mathrm{~nm})$ 를 사용하여 총 12 개의 분획물(Fr. 1-12)을 얻었다. 각 분획물에 대 하여 MPLC와 연계하여 활성유도 분획법(bioactivity-guided fractionation)을 통하여 생리활성물질을 분리하고자 하였다. 활 성 분획물을 농축하여 Forte (YMC, Japan)에 $\mathrm{C}_{18}$ column (YMC ODS AQ, $250 \times 20 \mathrm{~mm}, 10 \mu \mathrm{m}$, Japan)를 사용하여 증류 수 $(\mathrm{A}), \mathrm{MeOH}(\mathrm{B})$ 의 혼합 용매를 이동상으로 하는 0-5 min $50 \%$ (B), 5-35 min 100\% (B), 35-40 min 100\% (B) 조건으로 column chromatography를 실시 하여 유효화합물 1종을 분리하였 다. 분리한 nyasol은 UPLC 분석에서 추출물 중 nyasolo area는 약 $9.3 \%$, retention time은 6.87 분, UV $257 \mathrm{~nm}$, high resolution electronspray ionization mass spectrometry (HRESIMS) 값은 $251.1088[\mathrm{M}-\mathrm{H}]^{-}$를 가졌다.

화합물 1 ((-)-Nyasol) 황색 오일, $[\alpha]_{20}^{\mathrm{D}}=-130^{\circ}$ (c 0.50 , $\mathrm{MeOH}$ ), HRESIMS $m / z=251.1088[\mathrm{M}-\mathrm{H}]^{-}$(calcd for $\mathrm{C}_{17} \mathrm{H}_{15} \mathrm{O}_{2}$, 251.1072), $\lambda_{\max }(\mathrm{MeOH}) 257 \mathrm{~nm} .{ }^{1} \mathrm{H}-\mathrm{NMR}$ (methanol- $\left.d_{4}\right) \delta$ $4.42(1 \mathrm{H}, \mathrm{dd}, J=6.0,9.2 \mathrm{~Hz}, 3-\mathrm{CH}), 5.08(1 \mathrm{H}, \mathrm{m}, 5-\mathrm{CH})$, $5.63(1 \mathrm{H}, \mathrm{dd}, J=10.4,11.6 \mathrm{~Hz}, 2-\mathrm{CH}), 5.97(1 \mathrm{H}, \mathrm{ddd}$, $J=6.4,10.4,16.8 \mathrm{~Hz}, 4-\mathrm{CH}), 6.42(1 \mathrm{H}, \mathrm{d}, J=11.6 \mathrm{~Hz}, 1-$ $\mathrm{CH}), 6.70\left(2 \mathrm{H}, \mathrm{d}, J=8.4 \mathrm{~Hz}, 3 "-\mathrm{CH}_{2}\right), 6.70(2 \mathrm{H}, \mathrm{d}, J=8.4$ $\left.\mathrm{Hz}, 5 "-\mathrm{CH}_{2}\right), 6.74\left(2 \mathrm{H}, \mathrm{d}, J=8.4 \mathrm{~Hz}, 3^{\prime}-\mathrm{CH}_{2}\right), 6.74(2 \mathrm{H}, \mathrm{d}$, $\left.J=8.4 \mathrm{~Hz}, 5 '-\mathrm{CH}_{2}\right), 7.00\left(2 \mathrm{H}, \mathrm{d}, J=8.4 \mathrm{~Hz}, 2^{\prime \prime}-\mathrm{CH}_{2}\right), 7.00$ $\left(2 \mathrm{H}, \mathrm{d}, J=8.4 \mathrm{~Hz}, 6 "-\mathrm{CH}_{2}\right), 7.10\left(2 \mathrm{H}, \mathrm{d}, J=8.4 \mathrm{~Hz}, 2^{\prime}-\right.$ $\left.\mathrm{CH}_{2}\right), 7.10\left(2 \mathrm{H}, \mathrm{d}, J=8.4 \mathrm{~Hz}, 6 \mathrm{C}^{-} \mathrm{CH}_{2}\right) .{ }^{13} \mathrm{C}-\mathrm{NMR}$ (methanol$\left.d_{4}\right) \delta 127.5$ (C-1), 130.6 (C-2), 46.5 (C-3), 141.3 (C-4), 114.3 (C-5), 128.2 (C-1'), 129.7 (C-2'), 115.2 (C-3'), 156.5 (C-4'), 115.2 (C-5'), 129.7 (C-6'), 133.2 (C-1"), 128.3 (C-2"), 115.4 (C-3"), 155.8 (C-4"), 115.4 (C-5"), 128.3 (C-6") (Fig. 4A).

지모 에탄올 추출물의 UPLC-QTOF MS 분석. 지모 $100 \%$ 에탄올 추출물의 활성 지표물질의 정성분석을 위해 UPLCQTOF-MS 분석은 $\mathrm{BEH} \mathrm{C}_{18}(2.1 \times 100 \mathrm{~mm}, 1.7 \mu \mathrm{m})$ 칼럼관과 $\mathrm{PDA}$ 검출기를 장착한 UPLC에 유속 $0.4 \mathrm{~mL} / \mathrm{min}$, 용매는 $0.1 \%$ formic acid가 포함된 증류수(A)와 $\mathrm{ACN}(\mathrm{B})$ 을 사용하여 수행 하였다. UPLC 이동상의 용매조성은 0-1 min $10 \% \mathrm{~B}, 1-12$ $\min 98 \% \mathrm{~B}, 12-13.4 \min 98 \% \mathrm{~B}, 13.4-13.5 \min 10 \% \mathrm{~B}$, $13.5-15 \min 10 \% \mathrm{~B}$ 조건을 이용하였다.

DPPH radical 소거능 측정. 지모 추출물의 항산화 활성은 1,1-diphenyl-2-picrylhydrazyl (DPPH)을 사용하여 radical 소거 능을 측정하였다(Blois, 1958). DPPH radical에 대한 각 샘플의 환원력을 측정하기 위해 $\mathrm{MeOH}$ 에 각 샘플을 녹여 농도별로 희 석한 희석액 $800 \mu \mathrm{L}$ 와 $\mathrm{MeOH}$ 에 녹인 $0.2 \mathrm{mM} \mathrm{DPPH}$ 용액 $200 \mu \mathrm{L}$ 를 가하여 실온에서 30 분간 방치한 후 $517 \mathrm{~nm}$ 에서 흡광 
도를 측정하였다. 이때 활성을 비교하기 위하여 positive control 로 ascorbic acid를 사용하였다. DPPH radical 소거활성은 다음 식으로 계산하였다.

저해율 $(\%)$

$=\{1-($ 샘플첨가군의 흡광도/샘플무첨가군의 흡광도 $)\} \times 100$

Xanthine oxidase 저해 활성 측정. Xanthine oxide 저해활성 은 Stirpe와 Corte (1969)의 방법을 변형하여 측정하였다. 각 샘 플용액 $0.1 \mathrm{~mL}$ 과 $0.1 \mathrm{M}$ potassium phosphate buffer $(\mathrm{pH} 7.5)$ $0.6 \mathrm{~mL}$ 에 $2 \mathrm{mM}$ xanthine을 녹인 기질액 $0.2 \mathrm{~mL}$ 를 첨가하고 마 지막으로 동일한 buffer에 녹인 xanthine oxidase $(0.2 \mathrm{U} / \mathrm{mL})$ $0.1 \mathrm{~mL}$ 를 가하여 $37^{\circ} \mathrm{C}$ 에서 15 분간 반응시킨 후 $1 \mathrm{~N} \mathrm{HCl}$ $1 \mathrm{~mL}$ 를 가하여 반응을 종료시킨 다음, 반응액 중에 생성된 uric acid의 양을 $292 \mathrm{~nm}$ 에서 측정하였다. 저해 활성은 샘플용액의 첨가군과 무첨가군의 흡광도의 감소율로 다음 식을 이용해 계 산하였다.

저해율 $(\%)$

$=\{1-($ 샘플첨가군의 흡광도/샘플무첨가군의 흡광도 $)\} \times 100$

세포 배양. 마우스 대식세포인 RAW264.7 cell, 마우스 멜라노 마 세포인 $\mathrm{B} 16 \mathrm{~F} 10$ cell, 사람 각질형 세포인 $\mathrm{HaCaT}$ cell을 각 각 $1 \%$ antibiotic과 $10 \% \mathrm{FBS}$ 가 함유된 $\mathrm{DMEM}$ 배지를 사용 하여 $37^{\circ} \mathrm{C}, 5 \% \mathrm{CO}_{2}$ incubator에서 배양하였다.

세포 독성 측정. RAW264.7 cell을 $1.8 \times 10^{5} \mathrm{cell} / \mathrm{mL}$ 로 조절한 후 24 well plate에 접종하고 18시간 배양 후 샘플과 LPS (1 $\mu \mathrm{g} / \mathrm{mL}$ )를 동시 처리하여 24시간 배양하였다. 이후 배양 배지를 $3,000 \mathrm{rpm}$ 에서 5 분간 원심분리 하였다. 세포 독성을 평가하고자, lactate dehydrogenase (LDH) cytotoxicity assay kit를 이용하 여 microplate reader 장비를 사용하여 $490 \mathrm{~nm}$ 에서 흡광도를 측 정하였다 (Jeong 등, 2010). 각 샘플 군에 대한 평균 흡광도 값 을 구하였으며, 대조군의 흡광도 값과 비교하여 세포독성을 측 정하였다.

Nitric oxide (NO) 생성 억제 활성 측정. RAW264.7 cell로부 터 생성된 $\mathrm{NO}$ 의 양은 Griess 시약을 이용하여 세포배양액 중 에 존재하는 $\mathrm{NO}_{2}^{-}$의 형태로 측정하였다(Green 등, 1982). RAW264.7 cell을 $1.8 \times 10^{5} \mathrm{cell} / \mathrm{mL}$ 로 조절한 후 24 well plate 에 접종하고 18 시간 배양 후 샘플과 LPS $(1 \mu \mathrm{g} / \mathrm{mL})$ 를 동시 처 리하여 24시간 배양하였다. 배양액의 상층액을 얻은 후, 동량의 Griess 시약을 첨가하여 96 well plate에서 10 분간 반응시킨 후 $540 \mathrm{~nm}$ 에서 흡광도를 측정하였다.

세포 독성 측정. $\mathrm{B} 16 \mathrm{~F} 10$ cell을 $2.0 \times 10^{4}$ cells $/ \mathrm{mL}$ 로 96 well plate에 분주하고 18 시간 배양 후 샘플을 농도별로 처리하고 24 시간 배양하였다. 이후 $\mathrm{MTT}$ 용액 $50 \mu \mathrm{L}$ 를 첨가하여 4시간 동 안 반응 시켰다. 배양배지를 완전히 제거하고 DMSO $200 \mu \mathrm{L}$ 를 가하여 침전물을 완전히 용해시킨 후, microplate reader를 사용 하여 $540 \mathrm{~nm}$ 흡광도를 측정하였다. 각 샘플 군에 대한 평균 흡 광도 값을 구하였으며, 대조군의 흡광도 값과 비교하여 세포생 장률을 측정하였다.

Melanin 생합성 저해 활성 측정. B16F10 cell을 DMEM 배지 를 이용하여 $2.0 \times 10^{4}$ cells $/ \mathrm{mL}$ 로 24 well plate에 분주하고 $\alpha$ $\mathrm{MSH}(100 \mathrm{nM})$ 로 활성화 시킨 후 24시간 배양 후 샘플을 농도 별로 조제하여 첨가한 후 48시간 후에 $0.1 \mathrm{M}$ potassium phosphate buffer (pH 7.4)으로 세척하였다. 그 다음 melanin에 $1 \mathrm{~N} \mathrm{NaOH}$ 를 가하여 $80^{\circ} \mathrm{C}$ 에서 1시간 반응시킨 후 분광광도계 $405 \mathrm{~nm}$ 에서 흡광도를 측정하였다(Jeon 등, 2012). Melanin 생합 성 저해는 샘플 용액의 첨가군과 무첨가군의 흡광도 감소율로 나타내었으며, positive control로 arbutin $(30.0 \mu \mathrm{g} / \mathrm{mL})$ 과 kojic acid $(10.0 \mu \mathrm{g} / \mathrm{mL})$ 를 사용하였다.

Tyrosinase 저해 활성 측정. Tyrosinase 저해활성 측정은 Yagi 등(1986)의 방법에 따라 측정하였다. B16F10 cells를 배양하여 24 well plate에 각 well 당 세포를 $2.0 \times 10^{4} \mathrm{cell} / \mathrm{well}$ 가 되도록 분주하고 시료를 농도별로 조제한 후 처리하여 48시간 배양하 였다. 이후 각 well을 PBS로 2회 세척한 다음 $1 \%$ triton-x100 용액을 넣어 용해하고 eppendorf tube $(1.5 \mathrm{~mL}$, Sigma-Aldrich, $\mathrm{USA}$ )와 얼음을 사용해 3 회 정도 냉동 해동을 반복하여 $4^{\circ} \mathrm{C}$, $15,000 \mathrm{rpm} / 15$ 분 원심 분리한 상등액을 tyrosinase 저해 활성 측 정용액으로 사용하였다. 96 well plate에 이 효소액을 $40 \mu \mathrm{L}$ 넣 고 기질인 $\mathrm{L}-\mathrm{DOPA}(10 \mathrm{mM}) 100 \mu \mathrm{L}$, PBS $60 \mu \mathrm{L}$ 를 첨가하여 $37^{\circ} \mathrm{C}$ 에서 1 시간 반응 시킨 뒤 $475 \mathrm{~nm}$ 에서 흡광도를 측정하였 다. Positive control로 arbutin $(30.0 \mu \mathrm{g} / \mathrm{mL})$ 과 kojic acid $(10.0$ $\mu \mathrm{g} / \mathrm{mL}$ )를 사용하였다. Tyrosinase 저해 활성도는 대조군의 흡광 도에 대한 백분율로 계산하였다.

세포 독성 측정. 항 아토피 효능 평가를 위해 $\mathrm{HaCaT}$ cell을 각각 $3.0 \times 10^{5}, 2.0 \times 10^{5}$ cells $/ \mathrm{mL}$ 로 96 well plate에 분주하고 18 시간 배양 후 샘플을 처리하고 24시간 배양하였다. 이후 MTT 용액 $50 \mu \mathrm{L}$ 를 첨가하여 4 시간 동안 반응 시켰다. 배양배지를 완 전히 제거하고 $\mathrm{DMSO} 200 \mu \mathrm{L}$ 를 가하여 침전물을 완전히 용해 시킨 후, microplate reader를 사용하여 $540 \mathrm{~nm}$ 흡광도를 측정 하였다. 각 샘플 군에 대한 평균 흡광도 값을 구하였으며, 대조 군에 흡광도 값과 비교하여 세포생장률을 평가하였다.

염증성 chemokines 억제 활성 측정. $\mathrm{HaCaT}$ cell을 $3.0 \times 10^{5}$ cells $/ \mathrm{mL}$ 로 24 well plate에 분주하고 18시간 배양 후, IFN- $\gamma$ $(10 \mathrm{ng} / \mathrm{mL}), \mathrm{TNF}-\alpha(10 \mathrm{ng} / \mathrm{mL})$ 과 분리된 화합물을 농도별로 넣 은 후 24시간 배양하였다. 이후 세포 배양 배지를 원심 분리하 여 얻어진 상층액의 chemonkines 합성량을 측정하였다. 모든 샘 플은 정량 전까지 냉동보관 하였다. 염증성 chemokines는 human ELISA kit를 이용하여 측정하였다(Kang 등, 2013).

\section{결과 및 고찰}

DPPH radical 소거능 측정. 지모 뿌리줄기의 에탄올 농도별 추출물 $(30,50,70,100 \%)$ 과 물 추출물의 $\mathrm{DPPH}$ radical 소거 능을 측정한 결과는 Fig. $1 \mathrm{~A}$ 와 같다. 각 추출물을 15.63 , $31.25,62.5,125,250,500,1000 \mu \mathrm{g} / \mathrm{mL}$ 의 농도로 처리했을 때 모두 농도 의존적으로 $\mathrm{DPPH}$ radical이 소거 되었으며, $100 \%$ 에탄올 추출물이 가장 높은 소거능을 나타내며, $\mathrm{IC}_{50}$ $150.0 \mu \mathrm{g} / \mathrm{mL}$ 를 가졌다. 기존 보고된 식물 추출물들 중 삼백초 (Saururus chinensis Bail)와 돌콩(Glycine soya)의 항산화 활성 (Lee 등, 2006)과 비교에서 삼백초와 돌콩의 $100 \%$ 에탄올 추 출물은 $\mathrm{IC}_{50}$ 값이 각각 $446.74,952.05 \mu \mathrm{g} / \mathrm{mL}$ 의 수준으로 지모 에탄올 추출물은 항산화력이 매우 우수하였다.

Xanthine oxidase 저해 활성 측정. 지모 에탄올 농도별 추출 물과 물 추출물의 xanthine oxidase 저해활성을 측정한 결과는 Fig. $1 \mathrm{~B}$ 와 같다. 각 추출물을 $31.25,62.5,125,250,500$, $1,000 \mu \mathrm{g} / \mathrm{mL}$ 의 농도로 처리하였을 때 DPPH radical 소거능에 
(A)

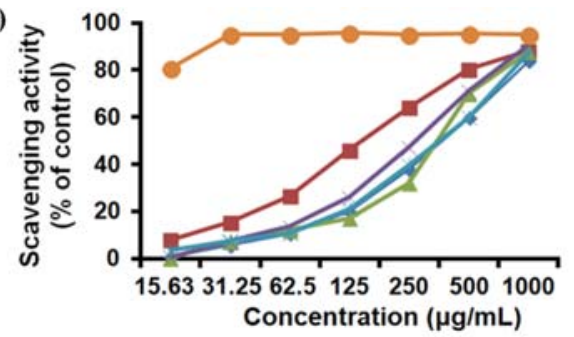

(B)

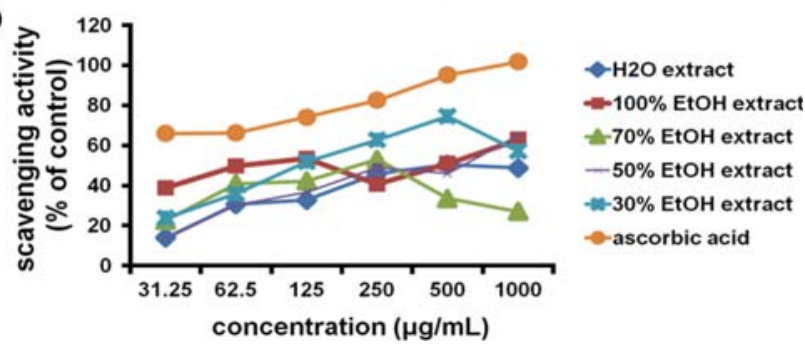

Fig. 1 Antioxidant activity change of $0-100 \%$ ethanol extracts from Anemarrhena asphodeloide evaluated by using two in vitro antioxidant models. (A) 1,1-diphenyl-2-picryl hydrazyl (DPPH) radical scavenging activity. (B) Xanthine oxidase inhibition activity. Ascorbic acid was used as positive control.

비해 농도 의존적이지 않고 뚜렷한 활성 차이가 나타나진 않지 만 최저 농도인 $31.25 \mu \mathrm{g} / \mathrm{mL}$ 에서도 $40 \%$ 수준의 저해활성을 나 타내었다. 이는 기능성 화장품의 원료로 사용 가능하다고 알려 진 상백피(Morus alba L.)의 에탄올 추출물이 $500 \mu \mathrm{g} / \mathrm{mL}$ 의 $\mathrm{IC}_{50}$ 값을 가지는 반면(Jee, 2009), 지모 에탄올 추출물은 약 3
배의 $125-250 \mu \mathrm{g} / \mathrm{mL}$ 의 $\mathrm{IC}_{50}$ 값을 가지므로 지모 에탄올 추출물 이 상백피 에탄올 추출물에 비해 다소 높은 xanthine oxidase 저해활성을 나타내는 것을 알 수 있다.

지모 에탄올 추출물의 UPLC-QTOF-MS 분석. 지모 $100 \%$ 에탄올 추출물의 활성 지표물질의 정성분석을 위한 UPLCQTOF-MS 분석 결과는 Fig. 2와 같다. 추출물의 chromatogram 에서 각각의 피크들의 HRESIMS 값을 확인한 결과 피크 1과 2는 각각 $421.0799[\mathrm{M}-\mathrm{H}]^{-}, 421.0757[\mathrm{M}-\mathrm{H}]^{-}$로 확인되었으며 피크 $3,4,5,6,7$ 의 $[\mathrm{M}-\mathrm{H}]^{-}$는 각각 $597.1211,259.0602$, $255.0685,257.1205,251.1088$ 로 확인하였다. 기존의 지모로부터 분리 보고된 물질들과 mass값과 chromatogram에서 retention time을 비교하여 피크 1과 2는 이성질체인 mangiferin (1)과 isomangiferin (2)로 확인하였으며(Kang 등, 2010; Joubert 등, 2003), 나머지 피크들도 기존의 지모로부터 분리된 화합물의 분 자량과 비교한 결과 norathyriol glycoside glucuronide (3), 2,4',6-trihydroxy-4-methoxybenzophenone (4), isoliquiritigen- in (5), broussonin A (6), nyasol (7)로 추정할 수 있었다(Bae, 2008; Youn 등, 2009; Liu 등, 2012).

MPLC 기반 NO 분흭물 활성 검정. 지모 $100 \%$ 에탄올 추출 물의 세포 독성 측정 결과 세포독성이 나타나지 않아 이를 바 탕으로 이전에 $\mathrm{HPLC}$ 를 기반으로 하는 분획물의 활성이 검증 되었던 프로토콜을 참고(Rueda 등, 2014) 하여. RAW264.7 cell을 LPS로 활성화시킨 후 지모 분획물이 $\mathrm{NO}$ 의 생성에 미치 는 효과를 관찰하기 위해 $1-12$ 번 분획물 $(100 \mu \mathrm{g} / \mathrm{mL})$ 에 LPS $(1 \mu \mathrm{g} / \mathrm{mL})$ 를 처리한 다음 24 시간 배양 후 $\mathrm{NO}$ 생성량을 측정하 였다. 지모 분획물(1-12번)의 NO 활성 검정 결과 1-4번 분획 물은 $\mathrm{NO}$ 의 양을 억제하지 못하는 반면, 5-12번 분획물은 $\mathrm{NO}$

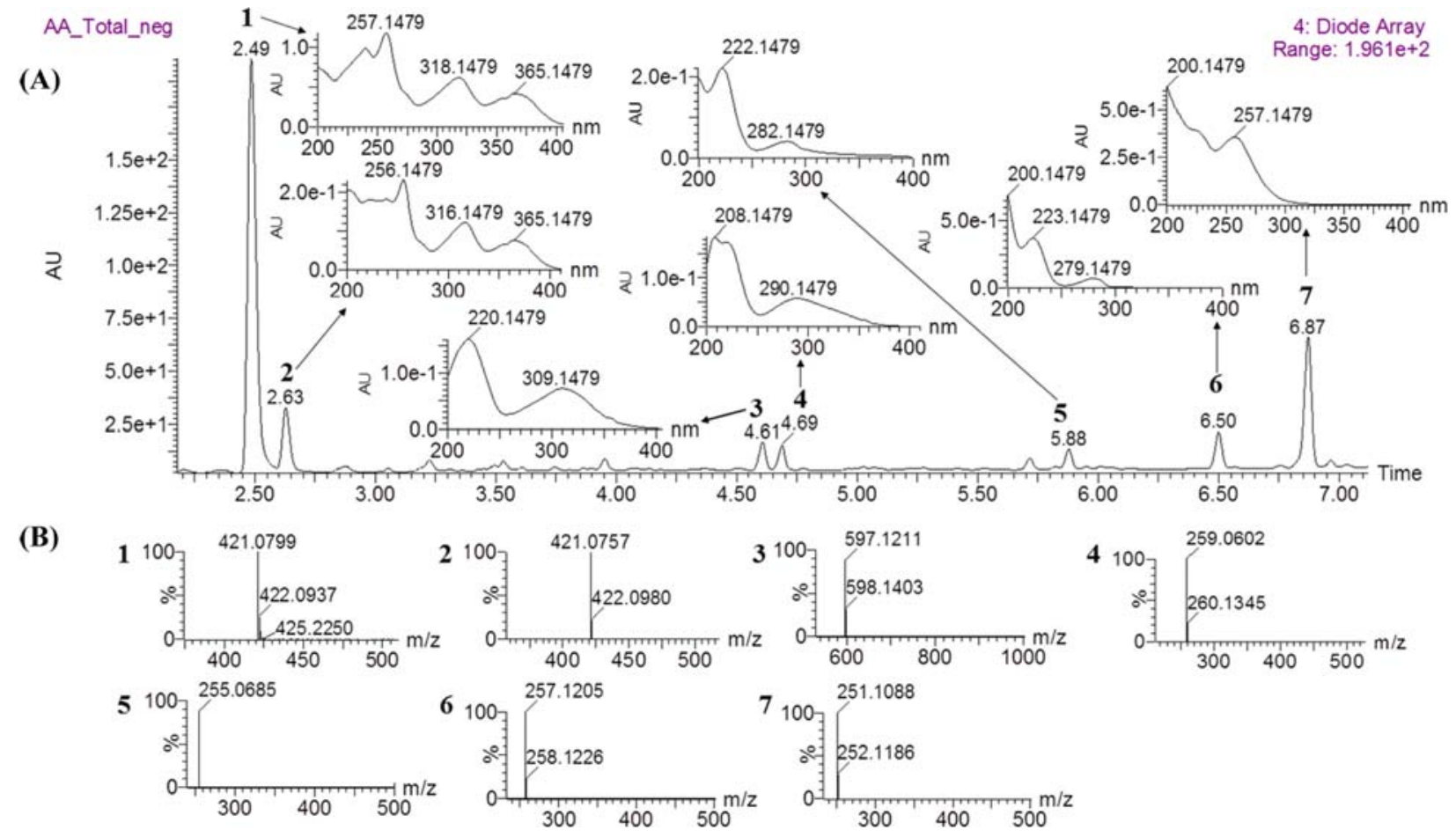

Fig. 2 UPLC-PDA chromatogram (A) and mass spectra (B) of 100\% EtOH extracts of Anemarrhena asphodeloide. Peaks: mangiferin (1), isomangiferin (2), norathyriol glycoside glucuronide (3), 2,4',6-trihydroxy-4-methoxybenzophenone (4), isoliquiritigenin (5), broussonin A (6), nyasol (7). 
(A)

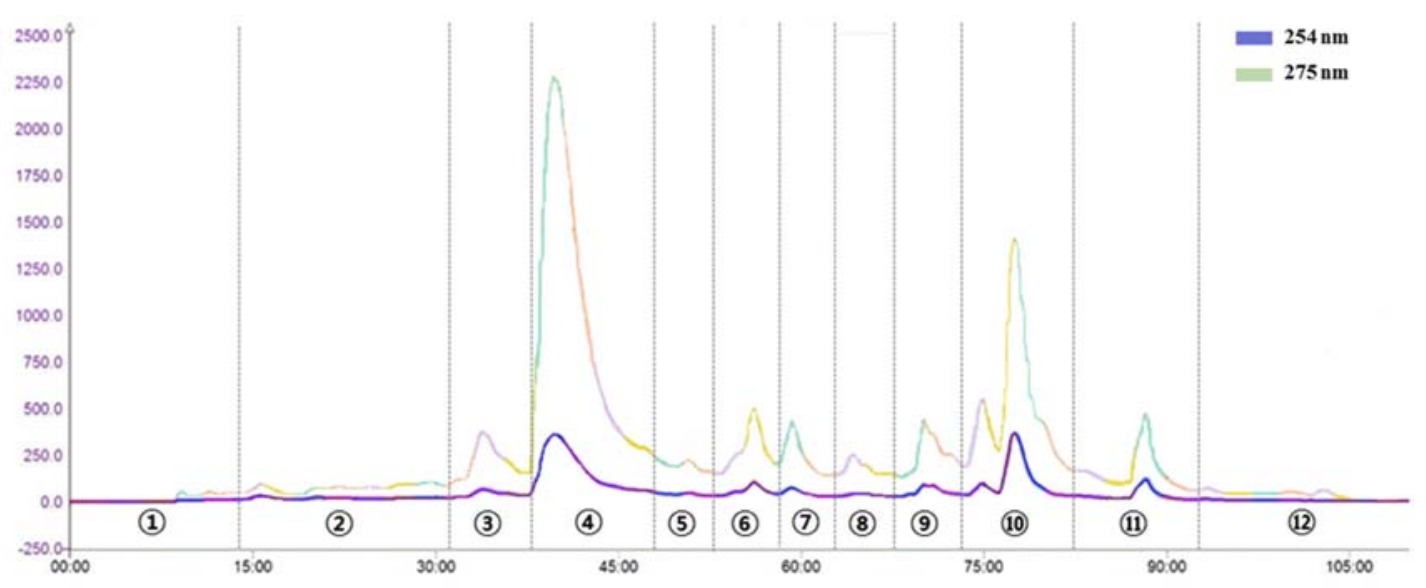

(B)

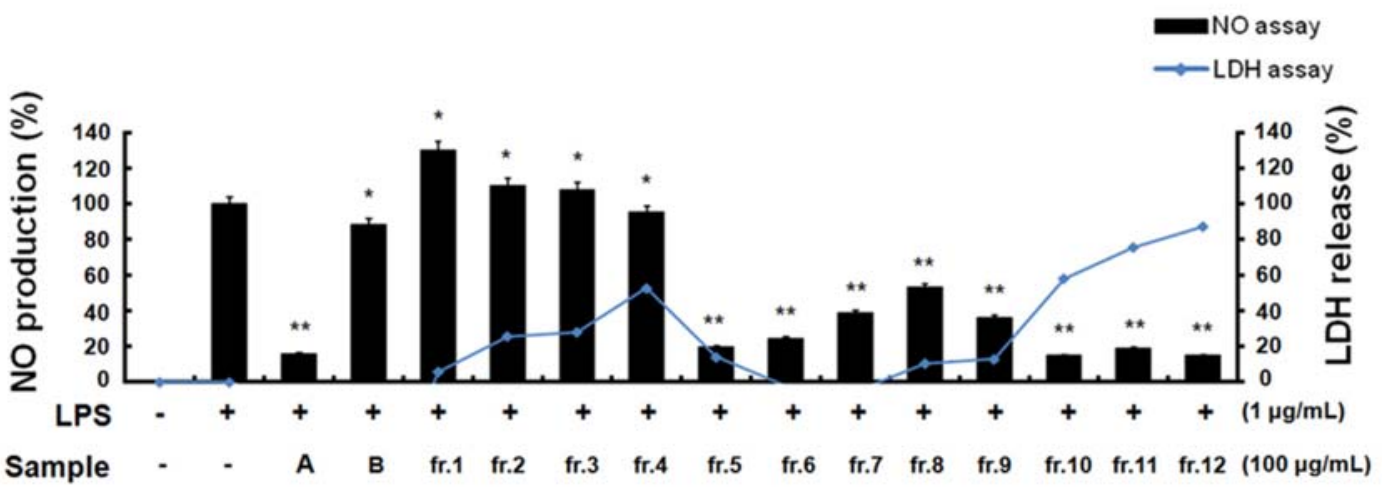

A : iNOS inhibitor (2-amino- 4-methylpyridine) B: 지모 $100 \%$ EtOH 추출물

Fig. 3 MPLC-based inhibitory activity profiling of a fractions 1-12 from Anemarrhena asphodeloide (A), for LDH release assay and NO production (B) in LPS-stimulated RAW264.7 macrophages. (A) MPLC chromatogram $(275 \mathrm{~nm})$ of a semipreparative separation of $6.8 \mathrm{~g}$ of extract. The 12 timebased fractions of main peak each are indicated with dashed lines. (B) RAW264.7 cells were treated with various concentrations of fractions 1-12 $(100 \mu \mathrm{g} / \mathrm{mL})$ for $24 \mathrm{~h}$, and the relative cell viability was assessed by LDH assay. RAW264.7 cells were treated with various concentrations of fractions 1-12 $(100 \mu \mathrm{g} / \mathrm{mL})$ for $1 \mathrm{~h}$ prior to the addition of LPS $(1 \mu \mathrm{g} / \mathrm{mL})$, and the cells were further incubated for $24 \mathrm{~h}$. The culture supernatant was subjected to a nitrite assay. Results expressed as the mean $\pm \mathrm{SD}$ of three independent experiments. ${ }^{*} p<0.005,{ }^{* *} p<0.001$ compared with treatment with LPS.

(A)<smiles>C=CC(/C=C\c1ccc(O)cc1)c1ccc(O)cc1</smiles>

(B)

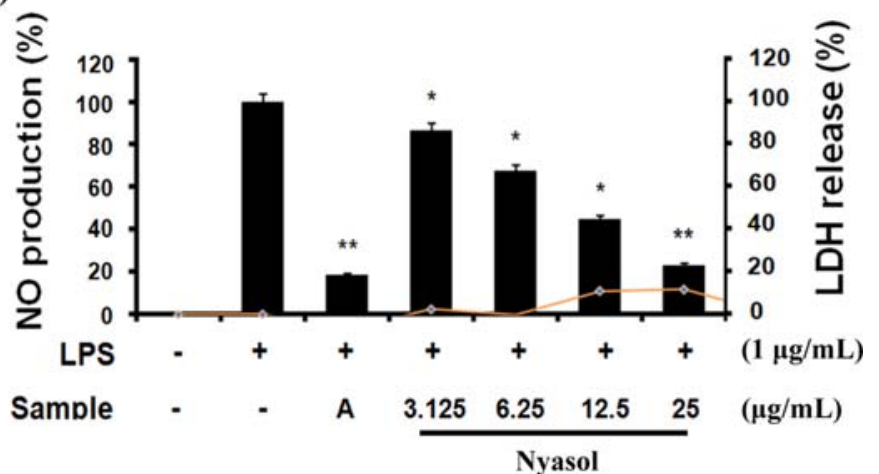

Fig. 4 (A) The structure of nyasol from A. asphodeloides. (B) Effect of nyasol on cell viability and NO production in LPS-stimulated RAW264.7 macrophages. RAW264.7 cells were treated with various concentrations of nyasol $(3.125,6.25,12.5$, and $25 \mu \mathrm{g} / \mathrm{mL})$ for $24 \mathrm{~h}$, and the relative cell viability was assessed by LDH relase assay. RAW264.7 cells were treated with various concentrations of nyasol $(3.125,6.25,12.5, \mathrm{and} 25 \mu \mathrm{g} / \mathrm{mL})$ for $1 \mathrm{~h}$ prior to the addition of LPS $(1 \mu \mathrm{g} / \mathrm{mL})$, and the cells were further incubated for $24 \mathrm{~h}$. The culture supernatant was subjected to a nitrite assay. Results expressed as the mean \pm SD of three independent experiments. ${ }^{*} p<0.005,{ }^{* *} p<0.001$ compared with treatment with LPS.

생성량을 유의성 있게 억제하였다(Fig. 3). 특히 10번 분획물은 가장 강한 활성을 나타냈지만 cell viability 측정 결과 세포독성
이 나타났다. 그러나 MPLC 크로마토그램 결과 10 번 분획물에 포함된 메인 화합물 농도가 매우 높아 독성이 나타난 것으로 
(A)

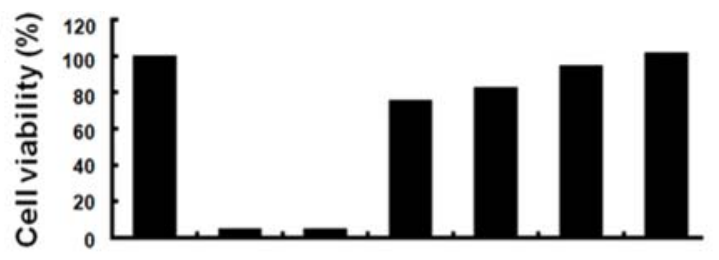

Sample Control $\begin{array}{llllll}200 & 100 & 50 & 25 & 12.5 & 6.25 \\ (\mu \mathrm{g} / \mathrm{mL})\end{array}$

(B)

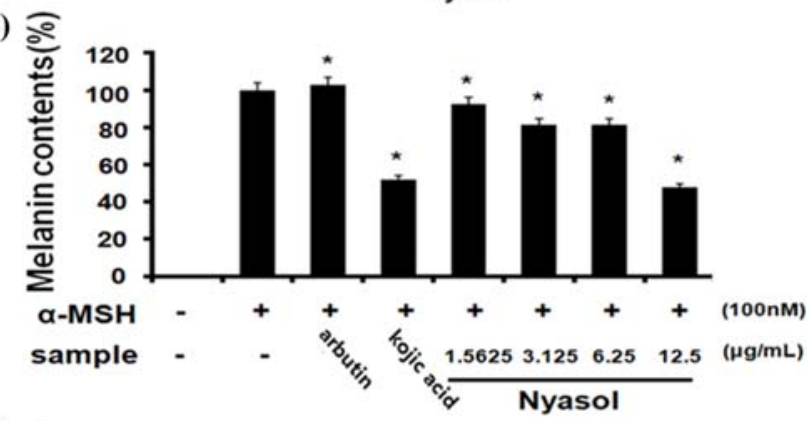

(C)

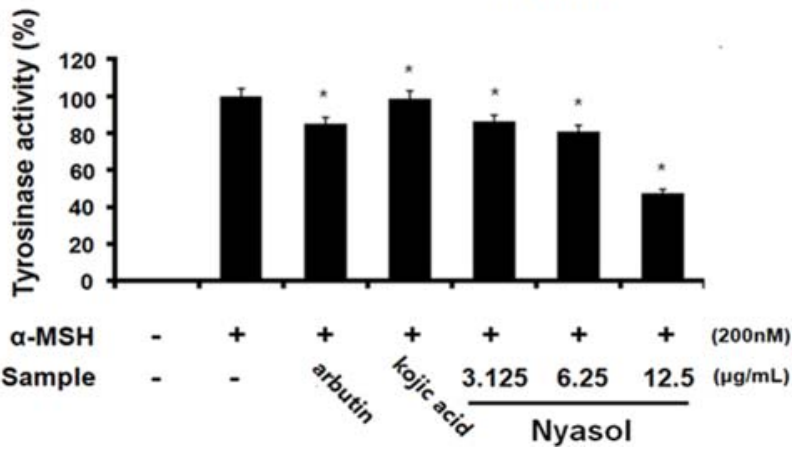

Fig. 5 (A) Effect of nyasol on the growth of B16F10 melanoma cells Cytotoxicity was measured by MTT assay of nyasol and control (DMSO) treated B16F10 melanoma cells after $24 \mathrm{~h}$ at the indicated concentrations. (B) Effect of nyasol on melanogenesis in B16F10 cells cultured with $3.125,6.25,12.5 \mu \mathrm{g} / \mathrm{mL}$ nyasol for 2 days. Changes of melanin contents that were pretreated with $\alpha$-melanocyte-stimulating hormone $(\alpha-\mathrm{MSH})$ and then cultured with nyasol $(3.125,6.25,12.5 \mu \mathrm{g} / \mathrm{mL}$ ) for $48 \mathrm{~h}$ $\left({ }^{*} p<0.01\right.$ when compared to an untreated control). Arbutin $(30.0 \mu \mathrm{g} /$ $\mathrm{mL})$, kojic acid $(10.0 \mu \mathrm{g} / \mathrm{mL})$ were used as positive control. (C) Cellular tyrosinase activity was determined using B16F10 cell lysates and nyasol $(3.125,6.25,12.5 \mu \mathrm{g} / \mathrm{mL})$. B16F10 cells were treated with nyasol $(3.125$, $6.25,12.5 \mu \mathrm{g} / \mathrm{mL}$ ) or arbutin and kojic acid (positive control) for $72 \mathrm{~h}$. Results expressed as the mean $\pm \mathrm{SD}$ of three independent experiments. ${ }^{*} p<0.005$ compared to the control (no treatment). Arbutin $(30.0 \mu \mathrm{g} / \mathrm{mL})$, kojic acid $(10.0 \mu \mathrm{g} / \mathrm{mL})$ were used as positive control.

생각되어 메인 화합물을 순수 분리한 후 독성이 없는 농도를 확인 후 NO 생성량을 측정하여 활성 화합물에 대한 활성실험 을 하였다.

Nyasol 분리 및 구조 분석. 10 번 분획물을 농축하여 Forte로 $\mathrm{C}_{18}$ column ( $\mathrm{YMC} \mathrm{ODS} \mathrm{AQ}$ )에 로딩 후 증류수와 $\mathrm{MeOH}$ 의 혼합 용매를 이동상으로 하여 $\mathrm{MeOH}$ 농도를 점차적으로 증가 시키면서 $(50 \rightarrow 100 \%, 40 \mathrm{~min})$ column chromatography를 실시 하였다. 1 회 주입량을 $200 \mu \mathrm{L}$ 로 하여 6 회 반복 실험을 통해 1 종의 활성 단일물질 $23.6 \mathrm{mg}$ 을 분리하였다.

분리된 물질은 황색 오일로 광학회전은 $[\alpha]_{20}^{\mathrm{D}}=-130^{\circ}$ (c 0.50 ,
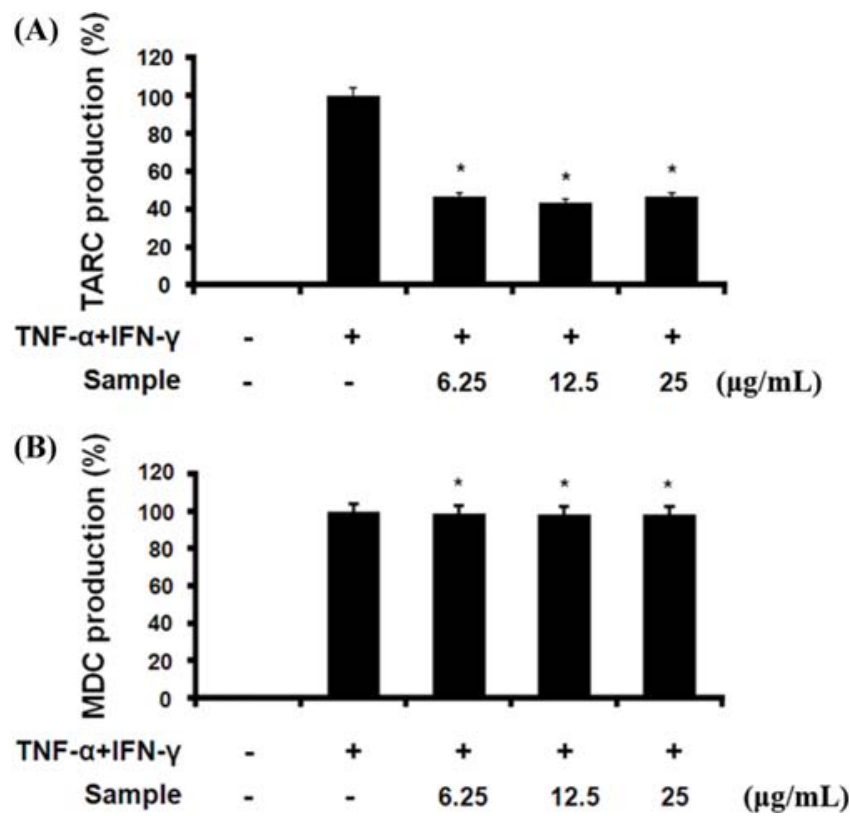

Fig. 6 Effect of nyasol on TARC (A) MDC expression levels (B) in TNF-alpha plus IFN-gamma induced HaCaT cells. Cells were pretreated with nyasol $(6.25,12.5,25 \mu \mathrm{g} / \mathrm{mL})$ for $1 \mathrm{~h}$ prior to TNF- $\alpha(10 \mathrm{ng} /$ $\mathrm{mL})+\mathrm{IFN}-\gamma(10 \mathrm{ng} / \mathrm{mL})$. Results expressed as the mean $\pm \mathrm{SD}$ of three independent experiments. ${ }^{*} p<0.005$ compared with co-treatment with TNF- $\alpha$ and IFN- $\gamma$.

$\mathrm{MeOH}$ )을 가지고 $\mathrm{HRESIMS}$ 에서 분자이온 $[\mathrm{M}-\mathrm{H}]^{-}$의 피크가 $m / z=251.1088$, 분자식은 $\mathrm{C}_{17} \mathrm{H}_{16} \mathrm{O}_{2}, \lambda_{\max }(\mathrm{MeOH}) 257 \mathrm{~nm}$ 의 흡광도를 나타내어 각각의 분광학적인 자료를 종합하면 이 화 합물은 norlignan계열 화합물로 예상할 수 있었다. 정확한 구조 확인을 위하여 $\mathrm{NMR}$ 를 이용하여 구조분석을 실시하여 ${ }^{13} \mathrm{C}-\mathrm{NMR}$ 스펙트럼에서는 17 개의 carbon peak가 관찰되었으며, ${ }^{1} \mathrm{H}-\mathrm{NMR}$ 스펙트럼에서 전형적인 $\mathrm{AABB}$ 시스템 $[7.10(2 \mathrm{H}, \mathrm{d}, J=8.4$ $\mathrm{Hz}), 7.00(2 \mathrm{H}, \mathrm{d}, J=8.4 \mathrm{~Hz}), 6.74(2 \mathrm{H}, \mathrm{d}, J=8.4 \mathrm{~Hz}), 6.70$ $(2 \mathrm{H}, \mathrm{d}, J=8.4 \mathrm{~Hz})]$ 을 가지는 para 위치에 두 개의 hydroxyl 기가 치환된 benzene링을 나타내었다. 상기 데이터를 종합한 결 과 분리된 화합물은 (-)-nyasol임을 확인하였다(Bae, 2008).

Nyasol의 NO 활성 평가. RAW264.7 cell을 LPS로 활성화시킨 후 nyasolo이 $\mathrm{NO}$ 의 생성에 미치는 효과를 관찰하기 위해 nyasol 을 $3.125,6.25,12.5,25 \mu \mathrm{g} / \mathrm{mL}$ 의 농도로 처리한 다음 24 시간 배양 후 NO 생성량을 측정하였다. 측정 결과 nyasol은 LPS로 유도된 $\mathrm{NO}$ 의 양을 유의성 있게 농도의존적으로 억제하였다(Fig. 4B). Nyasol이 LPS로 유도된 $\mathrm{NO}$ 의 생성을 감소시킨 것이 nyasol의 세포독성으로 인한 것인지를 관찰하기 위하여, nyasol 을 $3.125,6.25,12.5,25 \mu \mathrm{g} / \mathrm{mL}$ 의 농도로 처리하고 $\mathrm{LDH}$ assay 를 실시하여 cell viability를 측정하였다(Fig. 4B). 측정 결과 nyasol은 $12.5 \mu \mathrm{g} / \mathrm{mL}$ 의 농도에서 낮은 세포 독성을 나타냈지만 $\mathrm{IC}_{50}$ 이 $12.5 \mu \mathrm{g} / \mathrm{mL}(=40 \mu \mathrm{M})$ 수준으로 우수한 활성을 나타내었 고, 이는 기존 연구에서 독성이 낮고 활성이 높은 결과와도 일 치하였다(Lee 등, 2014).

세포 독성 측정. 샘플이 세포의 성장에 미치는 영향을 측정하 기 위하여 MTT 분석을 수행 하였다. 대사가 왕성한 살아있는 세포는, 세포 내 mitochondria의 탈 수소 효소작용에 의하여 수 용성의 노란색인 MTT tetrazoliumdm을 환원시켜 자주색을 띠 
는 비수용성 formazan을 형성 한다. 실험 결과 nyasol은 100 $\mu \mathrm{g} / \mathrm{mL}$ 이상의 농도에서는 독성을 나타내지만 $25 \mu \mathrm{g} / \mathrm{mL}$ 이하에 서는 독성이 낮게 관찰되었다. 특히 $12.5 \mu \mathrm{g} / \mathrm{mL}$ 에서는 control 수준으로 독성이 없는 것을 알 수 있다(Fig. 5A).

Melanin 생합성 저해 활성 측정. $\mathrm{B} 16 \mathrm{~F} 10$ cells을 $\alpha-\mathrm{MSH}$ 로 활성화 시킨 후 melanocyte에 nyasol을 처리함으로써 melanin 생성에 어떤 영향을 미치는지 알아보고자 하였다. B16F10 cells 에 nyasol을 $1.5625,3.125,6.25,12.5 \mu \mathrm{g} / \mathrm{mL}$ 의 농도로 처리 후 세포 내 melanin 양을 측정한 결과 농도 의존적으로 유의하 게 melanin 생합성 저해하는 효과를 나타내었다(Fig. 5B). $12.5 \mu \mathrm{g} / \mathrm{mL}$ 의 $\mathrm{IC}_{50}$ 값을 나타낸 nyasol은 미백소재로 알려진 kojic acid와 동등한 저해 활성을 나타내었다(Park 등, 2003b). Tyrosinase 저해 활성 측정. Nyasol의 $\mathrm{B} 16 \mathrm{~F} 10$ cells 내의 tyrosinase 저해 활성을 측정한 결과는 Fig. $5 \mathrm{C}$ 와 같다. Nyasol 을 $3.125,6.25,12.5 \mu \mathrm{g} / \mathrm{mL}$ 의 농도로 처리 했을 때 농도 의존 적으로 유의하게 세포내 주요 효소인 tyrosinase 활성을 저해하 는 것을 확인 할 수 있었다. Positive control로 Arbutin $(30.0 \mu \mathrm{g}$ / $\mathrm{mL})$ 과 kojic acid $(10.0 \mu \mathrm{g} / \mathrm{mL})$ 를 사용하였다. Nyasol은 $\mathrm{IC}_{50}$ 값이 $12.5 \mu \mathrm{g} / \mathrm{mL}$ 로 미백소재로 알려진 arbutin 보다 우수한 저 해 활성을 나타내었다(Jeong, 2012).

염증성 chemokines 억제 활성 측정. Nyasol의 $\mathrm{HaCaT}$ cell 내의 $\mathrm{TARC}$ 와 $\mathrm{MDC}$ 억제 활성을 측정한 결과는 Fig. 6과 같다. 처리 하지 않은 대조군에 비해, IFN- $\gamma$ 와 $\mathrm{TNF}-\alpha$ 를 처리한 처리 군에서 $\mathrm{TARC}$ 와 $\mathrm{MDC}$ 의 양이 유의적으로 증가한 것으로 보아 $\mathrm{IFN}-\gamma$ 및 $\mathrm{TNF}-\alpha$ 처리가 $\mathrm{HaCaT}$ cell의 염증을 효과적으로 유 도하였음을 알 수 있었다. Nyasol을 $6.25,12.5,25 \mu \mathrm{g} / \mathrm{mL}$ 의 농 도로 각각 처리 한 후 $\mathrm{TARC}, \mathrm{MDC}$ 를 측정한 결과, 비록 농 도 의존적인 결과는 아니지만 대조군에 비해 TARC 생성은 $50 \%$ 억제되었다. 하지만 $\mathrm{MDC}$ 생성은 억제되지 않았다. 이를 통해 nyasol이 염증 관련 chemokine인 TARC 생성을 억제시킴 으로써 기능성식품 혹은 화장품으로서의 응용이 가능하리라 사 료된다.

\section{초 록}

지모 뿌리를 $100 \%$ EtOH로 추출, 농축하여 medium pressure liquid chromatography 기반의 NO 분획물 활성 검정법을 이용 하여 활성을 검정하였다. preparative high performance liquid chromatography를 반복적인 칼럼크로마토그래피를 수행하여 1 개의 단일성분을 분리하였다. $\mathrm{NMR}, \mathrm{MS}$ 등을 포함한 이화학 및 분광학적 자료에 근거하여 분리된 물질을 구조 분석한 결과 (-)-nyasol로 구조동정 하였다. 분리된 활성물질 nyasol은 NO 생 성 억제, melanin과 tyrosinase를 억제하는 미백효과, thymus and activation-regulated chemokine 생성을 억제하는 활성에서 $6.25-12.5 \mu \mathrm{g} / \mathrm{mL}$ 의 $\mathrm{IC}_{50}$ 값을 가지는 강한 저해 활성을 나타냈 다. 특히 nyasol은 염증에 의한 항아토피 및 항미백활성에 있어 뛰어난 효능을 나타내었다. 이 결과로 보아 nyasol은 천연 기능 성 화장품으로써 이용 가능성을 넓힐 수 있을 것으로 사료된다.

Keywords 미백 · 지모 · 항산화 - 항아토피 · 항염증 - nyasol

감사의 글 본 논문은 산업통상자원부의 2012년 제주권 광역경제권 선도산 업의 지원을 받아 수행된 것임(과제번호 R0001465).

\section{References}

Azuma K, Nakayama M, Koshika M, Ippoushi K, Yamaguchi Y, Kohata K et al. (1999) Phenolic antioxidants from the leaves of Corchorus olitorius L. J Agric Food Chem 47, 3963-6.

Bae GR (2008) Identification of phenolic constituents as the active principles from Anemarrhena asphodeloides against Respiratory Syncytial Virus (RSV). MS Thesis, Ewha Womans University, Korea.

Blois MS (1958) Antioxidant determination by the use of a stable free radical. Nature 25, 1199-200.

Cho YJ (2011) Characteristics of cosmetic with whitening compounds from Phellodendron amurense. J Appl Biol Chem 54, 108-13.

Cho YJ, An BJ, and Kim JH (2011) Application of isolated tyrosinase inhibitory compounds from Persimmon leaves. Korean J Life Sci 21, 976-84.

Cho WG (2007) Comparison of drug delivery using hairless and pig skin. $J$ Korean Oil Chem Soc 24, 410-5.

Dong JX and Han GY (1991) A new active steroidal saponin from Anemarrhena asphodeloides. Planta Med 57, 460-2.

Green LC, Wagner DA, Glogowski J, Skipper PL, Wishnok JS, and Tannenbaum SR (1982) Analysis of nitrate, nitrite, and [15N] nitrate in biological fluids. Analytical Biochemistry 126, 131-8.

Hearing VJ and Jimenez M (1987) Mammalian tyrosinase the critical regulatory control point in melanocyte pigmentation. Int J Biochem 19, $1141-6$.

Jee SO (2009) Antioxidant activities and whitening effect of the Mulberry (Morus alba L.) root bark extracts. Korean J Plant Res 22, 145-51.

Jeon MJ, Kim MY, Jang HJ, Lee SW, Kim JH, Kim HS et al. (2012) Whitening effect of Hizikia fusiformis ethanol extract and its fractions. Journal of Life Science 22, 889-96.

Jeong HR, Kwak JH, Kim JH, Choi GN, Jeong CH, and Heo HJ (2010) Antioxidant and neuronal cell protective effects of an extract of Houttuynia cordata Thunb (a culinary herb) Korean J Food Preserv 17, 720-6.

Jeong YJ (2012) Kinetic analysis on tyrosinase inhibition activity of whitening agents, MS Thesis, Soongsil University, Korea.

Joubert E, Otto F, Gruener S, and Weinreich B (2003) Reversed-phase HPLC determination of mangiferin, isomangiferin and hesperidin in Cyclopia and the effect of harvesting date on the phenolic composition of $\mathrm{C}$. genistoides. Eur Food Res Technol 216, 270-3.

Kang MK, Jung IH, Hur JH, Kim SH, Lee JH, Kang JY et al. (2010) The analgesic and anti-inflammatory effect of WIN-34B, a new herbal formula for osteoarthritis composed of Lonicera japonica Thunb and Anemarrhena asphodeloides BUNGE in vivo. J Ethnopharmacol 131, 485-96.

Kang NJ, Kang GJ, Han SC, Hyun EA, Koo DH, Koh YS et al. (2013) Ceramium boydenii, a red alga, inhibits MDC/CCL22 production via suppression of STAT1 activation in HaCaT keratinocyte. Kor $J$ Pharmacogn 44, 154-60

Kawasaki T and Yamauchi (1963) Saponins of timo (Anemarrhena rizoma). II. Structure of timosaponin A-III. Chem Pharm Bull 11, 1221-4.

Kawasaki T, Yamauchi T, and Itakura N (1963) Saponins of timo (Anemarrhena rizoma). I. Yakugaku Zasshi 83, 892-69.

Kim GS, Park CK, Seong JD, Kim HT, Han SI, and Kwack YH (1999) Isolation and HPLC analysis of timosaponin A from rhizomes of Anemarrhena asphodeloides Bunge. Korean J Medicinal Crop Sci 7, 4550.

Kimura M, Kimura F, and Chen J (1996) Combined potentiating effects of Byakko-ka-ninjin-to, its constituents, rhizomes of Anemarrhena asphodeloides, timosaponin A III, and calcium on pilocarpine-induced saliva secretion in streptozotocin-induced diabetic mice. Biol Pharm Bull 19, 926-31.

Ko JS (2000) In Dermatology, Soomoonsa Press, Korea.

Lee EJ, Chung HJ, Pyee YN, Hong JY, Youn UJ, Seo EK et al. (2014) Suppression of Inducible Nitric Oxide Synthase Expression by Nyasol and Broussonin A, Two Phenolic Compounds from Anemarrhena asphodeloides, through NF-kB Transcriptional Regulation in vitro and in vivo. Chem Biodivers 11, 749-59. 
Lee JH, Chong MS, and Lee KN (2006) Antioxidative activity of medicinal plants from Korean. Kor J Oriental Preventive Medical Society 10, 1-9.

Liu H, Wu B, Pan G, He L, Li Z, Fan M et al. (2012) Metabolism and pharmacokinetics of mangiferin in conventional Rats, pseudo-germ-free rats, and streptozotocin-induced diabetic Rats. Drug Metab Dispos 40, 2109-18.

Morita N, Shimizu M, and Fukuta M (1965) Studies on the medical resources. XXIV. Chimonin in Anemarrhena rizoma. Yakugaku Zasshi 85, 374-5.

Nahumo S, Kishi SI, Inoue T, and Nagai M (1991) Saponins of Anemarrhena rizoma. Yakugaku Zasshi 111, 306-10.

Nakashima N, Kimura I, and Kimura M (1993) Isolation of pseudoprototimosaponin A III from rhizomes of Anemarrhena asphodeloides and its hypoglycemic activity in streptozotocin-induced diabetic mice. $J$ Nat Prod 56, 345-50.

Niwa A, Takeda O, Ishimaru M, Nakamoto Y, Yamasaki K, Kohda H et al. (1988) Screening test for platelet aggregation inhibitor in natural products. The active principle of Anemarrhena rizoma. Yakugaku Zasshi 108, 555-61.

Park SJ, Lee HY, and Oh DH (2003a) Free radical scavenging effect of seed and skin extracts from campell early grape (Viris labruscana B.). $J$ Korean Soc Food Sci Nutr 32, 115-8.

Park YM, Lee JS, Park JH, and Park DH (2003b) Effects of kojic acid, arbutin and vitamin $\mathrm{C}$ on cell viability and melanin synthesis in B16BL6 cell. J Soc Cosmet Scientists Korea 29, 151-67.

Pavel S and Muskiet FA (1983) Eumelanin (precursor) metabolites as markers for pigmented malignant melanoma, a preliminary report. Cancer Detect Prev 6, 311-8.

Prota G (1980) Recent advances in the chemistry of melanogenesis in mammals. $J$ Invest Dermatol 75, 122-7.

Rha YH (2005) Role of chemokines in the pathogenesis of atopic. Pediatr
Allergy Respir Dis 15, 238-41.

Rueda DC, De MM, Hering S, and Hamburger M (2014) HPLC-Based Activity Profiling for GABAA Receptor Modulators in Adenocarpus Cincinnatus. J Nat Prod 77, 640-9.

Son KH, Lee JM, Lee SH, Park JH, Kang SJ, Chang SY et al. (1999) Isolation and quantitative determination of anemarsaponin B from the rhizomes of Anemarrhena asphodeloides Bunge. Kor J Pharmacogn 30 , $163-7$.

Stirpe F and Corte ED (1969) The regulation of rat liver xanthine oxidase. $J$ Biochem 244, 3855-61.

Sun XH, Kizu H, and Tommory T (1992) Quantitative analysis of timosaponin B-II, timosaponin A-III and mangferin in Anemarrhena rizoma and Kampo prescriptions containing this crdue drug. Shoyakugaku Zasshi 46, 19-24.

Vestergaard C, Bang K, Gesser B, Yoneyama H, Matsushima K, and Larsen CC (2000) A Th2 chemokine, TARC produced by keratinocytes may recruit CLA+ CCR4+ lymphocytesinto lesional atopic dermatitis skin. $J$ Invest Dermatol 115, 640-6.

Yagi A, Kanbara T, and Morinobu N (1986) The effect of tyrosinase inhibition for aloe. Planta Medica 3981, 5179.

Yamakoshi J, Otsuka F, Sano A, Tokutake S, Saito M, Kikuchi M et al. (2003) Lightening effect on ultravioletinduced pigmentation of guinea pig skin by oral administration of a proanthocyanidin-rich extract from grape seeds. Pig Cell Res 16, 629-38.

Yoshie O, Imai T, and Nomiyama H (2001) Chemokines in immunity. Adv Immunol 78, 57-110.

Youn UJ, Lee YS, Jeong HN, Lee J, Nam JW, Lee YJ et al. (2009) Identification of Antiadipogenic Constituents of the Rhizomes of Anemarrhena asphodeloides. J Nat Prod 72, 1895-8. 